\title{
Salivary Trefoil Factor Family (TFF) Peptides and Their Roles in Oral and Esophageal Protection: Therapeutic Potential
}

\author{
Werner Hoffmann (1) \\ Institute of Molecular Biology and Medicinal Chemistry, Otto-von-Guericke University Magdeburg, \\ Leipziger Str. 44, 39120 Magdeburg, Germany; werner.hoffmann@med.ovgu.de
}

Citation: Hoffmann, W. Salivary Trefoil Factor Family (TFF) Peptides and Their Roles in Oral and Esophageal Protection: Therapeutic Potential. Int. J. Mol. Sci. 2021, 22 12221. https://doi.org/10.3390/ ijms222212221

Academic Editors: Antonio Lucacchini, Laura Giusti and Claudia Desiderio

Received: 27 October 2021

Accepted: 10 November 2021

Published: 12 November 2021

Publisher's Note: MDPI stays neutral with regard to jurisdictional claims in published maps and institutional affiliations.

Copyright: (C) 2021 by the author. Licensee MDPI, Basel, Switzerland. This article is an open access article distributed under the terms and conditions of the Creative Commons Attribution (CC BY) license (https:// creativecommons.org/licenses/by/ $4.0 /)$.

\begin{abstract}
Human saliva is a complex body fluid with more than 3000 different identified proteins. Besides rheological and lubricating properties, saliva supports wound healing and acts as an antimicrobial barrier. TFF peptides are secreted from the mucous acini of the major and minor salivary glands and are typical constituents of normal saliva; TFF3 being the predominant peptide compared with TFF1 and TFF2. Only TFF3 is easily detectable by Western blotting. It occurs in two forms, a disulfide-linked homodimer (Mr: 13k) and a high-molecular-mass heterodimer with IgG Fc binding protein (FCGBP). TFF peptides are secretory lectins known for their protective effects in mucous epithelia; the TFF3 dimer probably has wound-healing properties due to its weak motogenic effect. There are multiple indications that FCGBP and TFF3-FCGBP play a key role in the innate immune defense of mucous epithelia. In addition, homodimeric TFF3 interacts in vitro with the salivary agglutinin DMBT1gp340. Here, the protective roles of TFF peptides, FCGBP, and DMBT1gp340 in saliva are discussed. TFF peptides are also used to reduce radiotherapy- or chemotherapy-induced oral mucositis. Thus, TFF peptides, FCGBP, and DMBT1gp340 are promising candidates for better formulations of artificial saliva, particularly improving wound healing and antimicrobial effects even in the esophagus.
\end{abstract}

Keywords: saliva; artificial saliva; esophagus; TFF3; FCGBP; DMBT1; lectin; mucin; innate immune defense; xerostomia

\section{Introduction \\ 1.1. Saliva}

Saliva is a mixed body fluid produced in the oral cavity by different sources, i.e., three pairs of major salivary glands (parotid, sublingual, and submandibular glands) and several minor glands, such as labial and palatal glands. The parotid glands contain only serous acini, whereas all other glands are composed of a mixture of seromucous acini. Saliva is the fluid which has the first contact with ingested food and often the environment. It fulfills important functions for both nutrition (lubrication of the bolus, taste, and first steps of digestion) as well as for protection, particularly of the teeth, the oral epithelial barrier, but also the esophagus (reviews: [1-4]). For example, saliva has enzymatic, wound healing (cell migratory), and antimicrobial effects $[1,4]$. It is also essential for maintaining healthy oral microbiota $[2,5]$.

Within the last two decades, the saliva proteome was subjected to a huge number of investigations, which often focused on highly specific aspects, such as certain diseases (also use of saliva as diagnostic fluid) and response to different stimuli, such as psychological stress ("stimulated saliva") [6-8]. Recently, not only whole saliva was investigated, but also extra-vesicles-enriched saliva, which contains exosomes, i.e., extracellular vesicles, which probably originate from intracellular multivesicular bodies [9]. In normal saliva, more than 3000 proteins were identified with a relative abundance spanning about 14 orders of magnitude [6]. Only about 200 proteins represent about $90 \%$ in weight including prolinerich proteins, mucins, amylases, histatins, and statherins [5]. Of note, there are remarkable 
individual differences and the saliva composition is also subject to hormonal fluctuations and aging [3-5].

Typical salivary protein constituents are enzymes (such as amylases, lysozyme), protease inhibitors, growth factors such epidermal growth factor (EGF), antimicrobial peptides (such as histatins, defensins, cathelicidin), immunoglobulins (mainly secretory IgA and IgG), surfactant proteins, the agglutinin Deleted in Malignant Brain Tumor 1/gp340 $\left(\mathrm{DMBT}^{\mathrm{gp}}{ }^{340}\right.$ ), IgG Fc binding protein (FCGBP), and secretory mucins (MUC5B, MUC7, MUC19) [2,5,10-13]. Many of these proteins also appear in tears [12]. Furthermore, there are proteins unique to this fluid, such as proline-rich proteins and statherins, which influence calcium phosphate chemistry and initial plaque formation; for example, statherin allows saliva to maintain a state of supersaturation concerning calcium phosphate $[1,3,5]$. Of note, most salivary proteins appear in protein families.

Mucins are glycoconjugates and the primary gel-forming components of mucus. Due to their special rheological properties, they are effective in lubricating the oral cavity including the teeth. They also play a key role for the innate immune defense of the oral cavity (review: [10]). The salivary mucins mainly appear in two molecular entities, the unusual low molecular mass mucin MUC7 (previously termed MG2) and the high-molecular-mass mucin MUC5B (previously MG1). Additionally, MUC19 has been identified on the transcript and protein level [10,14]. MUC5B, MUC7, and MUC19 are typically expressed in the mucous acini of the major and minor salivary glands [14]. MUC5B and MUC19 are typical gel-forming mucins, which evolved from a common ancestor with von Willebrand factor. In contrast, MUC7 lacks gel-forming properties. Both MUC5B as well as MUC7 form complexes with proline-rich proteins, statherins, and histatin 1 [10]. However, MUC5B and MUC7 differ remarkably in their binding characteristics with microbes [10]. MUC7 directly binds Streptococcus strains, but also to Escherichia coli and Staphylococcus aureus. Sialic acid residues from the carbohydrate moiety of MUC7 play a major role for binding of different microbes. In contrast, the binding of MUC5B to oral pathogens is limited and here protein-protein interactions seem to be important, e.g., for binding of Haemophilus parainfluenzae. MUC5B also reduces the virulence of Candida albicans. Furthermore, a mixture of MUC5B and MUC7 inhibits T cells from viral infections, i.e., HIV-1. Generally, there are two potential principles by which salivary mucins could protect the oral cavity; they could agglutinate microbes facilitating their removal or they disperse the microbes, hindering their transition into a virulent state [10].

Generally, saliva has a fundamental role for the innate immune system of the oral cavity, but also the esophagus and the delicate esophagogastric junction. Here, a wide range of different molecular mechanisms is used, such as adhesions (proline-rich proteins), agglutinins (e.g., mucins, DMBT1 ${ }^{\text {gp } 340}$ ), and antimicrobial peptides $[1,2,4,5,10,11]$. On the other hand, saliva is important for taste, digestion, and modulating the $\mathrm{pH}$; it has pronounced rheological properties important for lubrication (mucins, etc.), but it also has to provide the necessary water by aquaporins (water channels) $[1,2,4,5,14]$. The importance of a functional salivary flow can be estimated from patients with a catastrophic loss of salivary function, such as patients with radiation therapy because of head and neck cancers, patients with congenital absence of salivary glands, and patients with Sjögren's syndrome [3,4,9]. Thus, there is still a need for the development for better formulations of saliva substitutes, particularly with strongly improved antimicrobial properties (see Section 3.2).

\subsection{Trefoil Factor Family (TFF) Peptides}

More than two decades ago, expression of TFF peptides was also demonstrated in human salivary glands, where TFF3 transcripts were most abundant [15]. In saliva, only TFF3 is easily detectable by Western blotting, but not TFF1 or TFF2 [15-17]. The concentration of salivary TFF1 was reported to be about $20 \%$ of that of TFF3, whereas the salivary TFF2 concentration was below $1 \%$ of that of TFF3 [18]. In situ hybridization, laser microdissection, and immunohistochemistry localized TFF expression mainly in mucous acini of both the major and minor salivary glands, TFF3 expression being most abundant $[14,19]$. There 
were remarkable individual differences, also sometimes recognizing TFF3 in serous acini of submandibular glands [15]. TFF3 was also located in parotid gland ducts [20]. Furthermore, TFF3 (and also little TFF1 and TFF2) is synthesized in the oral mucosal epithelium [16,21]. Expression of TFF2 and TFF3 in oral mucosal tissue is downregulated in patients with oral squamous cell carcinoma and oral lichen planus [21,22]. Decreased salivary TFF3 levels were also observed in patients with obstructive sleep apnea and rhonchopathy [23]. Salivary TFF1 and TFF3 concentrations are reduced in patients with chronic periodontitis [24], whereas salivary TFF3 is elevated in children with oral mucositis [25]. TFF expression is increased in salivary gland tumors [26].

TFF peptides belong to a family of secretory lectins (i.e., sugar-binding proteins), which play different roles for mucosal protection (for recent reviews, see $[27,28]$ ). Thus, they are also considered as a protective shield of the oral cavity [29]. They consist of one (TFF1, TFF3) or two TFF domains (TFF2), each TFF domain being stabilized by three conserved disulfide bridges, i.e., Cys ${ }^{\mathrm{I}-\mathrm{V}}$, Cys ${ }^{\mathrm{II}-\mathrm{IV}}$, Cys ${ }^{\mathrm{III}-\mathrm{VI}}$ (Figure 1; for reviews, see [28,30,31]). Of note, and highly unusual for secretory peptides, TFF1 and TFF3 contain an odd number of cysteine residues, the seventh unpaired residue (Cys ${ }^{\mathrm{VII}}$ ) being C-terminal and outside the TFF domain. The nucleophilicity of $\mathrm{Cys}^{\mathrm{VII}}$ is modulated by neighboring acidic residues (change of pKa) as well as by steric exposure due to proline residues nearby (Figure 1). This is highly relevant for TFF1, which is directly flanked by four acidic residues and mainly occurs in the stomach as an unusual monomer.
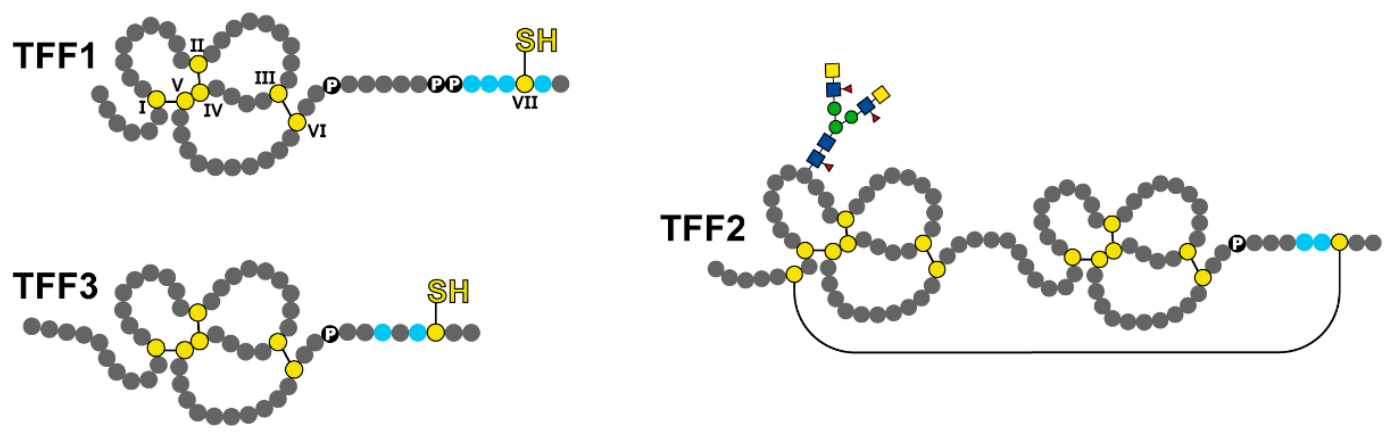

Figure 1. Schematic structures of the human TFF peptides TFF1, TFF2, and TFF3. Cysteine residues (C; numbering in Roman numerals) as well as the free thiol groups at Cys ${ }^{\mathrm{VII}}$ in TFF1 and TFF3 are shown in yellow. TFF2 contains an N-linked carbohydrate moiety and an additional disulfide bridge between Cys- 6 and Cys-104, which creates a circular structure. Additionally outlined are the proline residues $(\mathrm{P})$ at the $\mathrm{C}$-terminal outside the TFF domains. Acidic residues close to the $\mathrm{C}$-terminal cysteine residues are shown in blue.

TFF peptides are characteristically secreted by mucous epithelia and their glands. Here, exocrine secretion occurs, mainly together with different gel-forming mucins [27,28]. TFF1 is predominantly secreted from gastric surface mucous cells and TFF2 from gastric mucous neck and antral gland cells. In contrast, TFF3 is mainly synthesized in intestinal goblet cells, but also in most other mucous epithelia, such as the respiratory and urogenitary tracts and also the conjunctiva. Furthermore, TFF peptides also undergo endocrine secretion, where minute amounts are released from the central nervous system, the immune system, the endocrine pancreas, and the thyroid $[27,28]$. TFF peptides are linked to inflammation (review: [32]) and they play different roles in the mucosal innate immune defense (review: [33]). Here, I will discuss the role of salivary TFF peptides for the protection of the oral cavity, the esophagus, and also the delicate esophagogastric junction as well as their therapeutic potential, for example as constituents for improved formulations for artificial saliva. Major emphasis will be put on TFF3, as this is the predominant salivary TFF peptide in human. 


\section{Potential Roles of Salivary TFF Peptides}

\subsection{Potential Role of Salivary TFF1}

Little TFF1 expression was detectable in mucous acini of submandibular, sublingual, and labial as well as in parotid glands $[14,15,19]$. Due to the minute amounts of TFF1 expected in the saliva, there are no protein data available thus far and it is not clear in which forms salivary TFF1 occurs. However, the situation in the human and murine stomach has been investigated in detail, where large amounts of TFF1 are synthesized [34,35]. Here, TFF1 mainly occurs as an unusual monomer, but also as a homodimer and as heterodimers with FCGBP and gastrokine $2[34,35]$. By analogy, one might expect that salivary TFF1 might also occur as a monomer, a homodimer, and a TFF1-FCGBP heterodimer, as FCGBP is a constituent of human saliva [12,17]. The hypothetical existence of a TFF1-FCGBP heterodimer would be also comparable with the TFF3-FCGBP heterodimer present in human saliva [17].

Monomeric TFF1 with its free and probably highly nucleophilic thiol group at Cys VII (due to flanking acid residues and steric exposure; see Figure 1) could hypothetically act as a scavenger for reactive oxygen species (ROS) as discussed previously in detail [27,34-36]. In short, the free thiol at Cys VII is masked by the four flanking acidic amino acids and thus escapes assembly (dimerization), retention, or degradation in the endoplasmic reticulum, similar to that described for Ig light chains [27]. This might be of biological significance as saliva is a rich source for ROS due to the generation of $\mathrm{H}_{2} \mathrm{O}_{2}$ by dual oxidase (DUOX) 2 from salivary glands and secreted lactoperoxidase, which produces microbicidal hypothiocyanite $\left(\mathrm{OSCN}^{-}\right)$anions $[3,37]$. Such a protective function as ROS scavenger might also be of special importance for the delicate esophagogastric junction, as reactive nitrogen species (RNS) are also formed there when nitrite from saliva meets the gastric juice [27]. As a prerequisite, salivary nitrate $\left(\mathrm{NO}_{3}{ }^{-}\right)$, whose concentration is about 10-20 times higher than that in plasma due to the enterosalivary circulation, is reduced to nitrite $\left(\mathrm{NO}_{2}{ }^{-}\right)$by the oral microbiome $[27,38,39]$. After acidification in the gastric juice and disproportionation of the instable nitrous acid (HO-NO), the radical nitric oxide (NO) is formed, which is a gasotransmitter and can also react with $\mathrm{O}_{2}{ }^{-}$to peroxynitrite $\left(\mathrm{ONOO}^{-}\right)[27,38]$. The latter is the prototype of a toxic RNS [27]. Thus, it could well be that salivary TFF1 might reduce the development of adenocarcinoma particularly at the delicate esophagogastric junction.

Additionally, monomeric TFF1 could be an intracellular chaperone involved in the correct folding of glycoproteins (such as mucins) in the endoplasmic reticulum [27,32]. In contrast, homodimeric TFF1 is able to interact as a lectin with Helicobacter pylori (for review, see [40]). Homodimeric TFF1 can also bind as a lectin to the gastric mucin MUC6 in vitro [34], which could also stabilize the inner gastric mucus layer particularly at the delicate esophagogastric junction.

The hypothetical formation of a salivary TFF1-FCGBP heterodimer is most interesting as it could play a role in the innate immune defense of the oral cavity and the esophagus comparable with TFF3-FCGBP (see Section 2.3). Furthermore, by analogy with the situation in the stomach, the formation of additional TFF1 heterodimers is possible [34,35].

\subsection{Potential Role of Salivary TFF2}

Only minute amounts of TFF2 are expressed in mucous acini of major and minor salivary glands $[14,19]$ and there are no protein data on TFF2 in the saliva.

Based on studies from the stomach, where TFF2 is a major secretory peptide of mucous neck and antral gland cells together with the mucin MUC6, it is clear that TFF2 is a typical lectin specifically recognizing the GlcNAc $\alpha 1 \rightarrow 4 \mathrm{Gal} \beta 1 \rightarrow \mathrm{R}$ epitope at the non-reducing terminals of the MUC6 carbohydrate moiety (for review, see [41]). A prerequisite for the biosynthesis of this unusual sugar epitope is $\alpha 1,4-\mathrm{N}$-acetylglucosaminyltransferase (A4GNT) and mice lacking this enzyme spontaneously develop antral adenocarcinomas [42]. Gastric TFF2 has probably a role in physically stabilizing the inner insoluble layer of the gastric mucus barrier (crosslinked mucous network) and thus can be considered as part of the gastric innate immune defense $[27,28,33,43,44]$. Furthermore, TFF2 has been re- 
ported to influence inflammatory processes probably via glycosylated basolateral receptors (for reviews, see [28,32]).

Currently, the biological role of salivary TFF2 is not established and it is not even clear if it is bound to mucins or if it exists in a non-bound form similar to that in the porcine pancreas [45]. There are no positive reports on MUC6 expression in salivary glands; MUC6 transcripts are absent in the esophagus, but they can easily be detected in the stomach starting at the Z-line [46]. There are also no reports on the expression of A4GNT in salivary glands and the esophagus. Thus, there is no indication for an interaction of salivary TFF2 with MUC6 or another mucin in the oral cavity or the esophagus. Possibly salivary TFF2 helps to protect the delicate esophagogastric junction. Furthermore, salivary TFF2 seems to bind as a lectin ligand to the carbohydrate moiety of various transmembrane receptors affecting, e.g., cell migration or an immune response (for reviews, see [28,32].

\subsection{Potential Role of Salivary TFF3}

In contrast to TFF1 and TFF2, TFF3 is easily detectable in human saliva and is mainly expressed in mucous acini of the major and minor salivary glands together with the mucin MUC5B [14,15]. About 20 to $80 \%$ of human salivary TFF3 exist in a high-molecularmass form, which represents a TFF3-FCGBP heterodimer (Figure 2A) [17]. The lowmolecular-mass fractions mainly represent different homodimeric TFF3 forms [17,47]. In the latter, a truncated TFF3 form was also characterized missing the C-terminal phenylalanine residue [17]. Degradation of salivary TFF3 might occur due to the presence of pepsin or bacterial proteases from the oral microbiome; of note, in $22 \%$ of healthy volunteers, pepsin/pepsinogen was detected in the saliva [48].

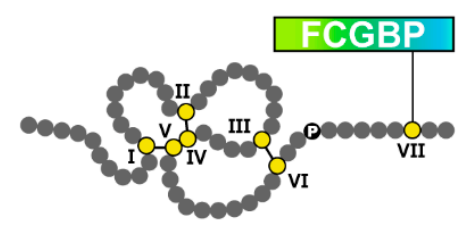

A TFF3-FCGBP

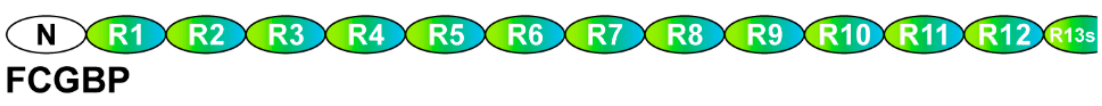

DMBT1 $19340 \quad 00000000000010$

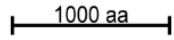

Figure 2. Schematic structures of the human TFF3-FCGBP heteromer (A) as well FCGBP and DMBT1gp340 (B). (A) TFF3 forms a three-leafed structure (TFF domain) by three disulfide bridges between Cys ${ }^{\mathrm{I}}$ to $\mathrm{Cys}{ }^{\mathrm{VI}}$. The 7 th cysteine residue is linked to the high molecular mass glycoprotein FCGBP (see panel B) via a disulfide bridge (not drawn to scale). Cysteine residues are shown in yellow. Additionally represented is a characteristic proline residue (P) separating the TFF domain from Cys ${ }^{\mathrm{VII}}$. (B) Schematic structures of the high-molecular mass glycoproteins FCGBP and DMBT1gp ${ }^{340}$. Outlined are the various modules; some of them are repetitive and cysteine-rich, e.g., R1-R13s, S1-S14 (SRCR domains). Sale bar: 1000 amino acid residues.

The biological function of homodimeric TFF3 in the saliva is not known currently. However, a protective role can be expected for both the oral epithelium as well as the esophagus [49]. Of note, the esophageal epithelium contains few submucosal glands, which also secrete TFF3 [46]. Taken together, the synthesis of TFF3 in salivary glands is reminiscent to TFF3 synthesis in glandular structures of the esophagus, the lung, and the cervix uteri, where TFF3 is co-secreted with the mucin MUC5B [46,50,51]. A possible protective role of TFF3 can be inferred from its weak motogenic and antiapoptotic activities (for review, see [27]). These cell migratory and survival effects are coordinately regulated in order to ensure synergy, e.g., wound healing (restitution) [52]. Recombinant human TFF3 dimer enhances migration of oral keratinocytes [53,54]. However, the motogenic effect is rather weak and might result from a lectin-triggered activation of basolateral transmembrane glycoproteins, such as CXCR4 and CXCR7 [55] (for reviews, see [27,28,56]). Of special note, the potential wound healing effect of TFF3 could be even enhanced in vivo by EGF (a typical constituent of human saliva) as synergistic motogenic effects were described with TFF peptides [57-59]. 
There are increasing indications that the high-molecular-mass TFF3-FCGBP heterodimer plays a key role for the mucosal innate immune defense (for review, see [33]). TFF3-FCGBP was originally characterized in the human intestine, where TFF3 is mainly expressed [60]. FCGBP is a secretory, repetitive, cysteine-rich glycoprotein comprising of about 5400 amino acid residues (see Figure 2B) [61], which is auto-catalytically processed at the $11 \mathrm{GD} / \mathrm{PH}$ sites with preferential processing at the six WGD/PH sites [60]. However, after processing, the proteolytic fragments are still linked by disulfide bridges [60]. The cysteine-rich repeats show similarity with von Willebrand factor and gel-forming mucins, such as MUC5B. FCGBP is ubiquitous in vertebrates [62] and is typically synthesized by numerous mucous epithelia and their glands, such as salivary glands, and thus is a constituent of many body fluids, such as saliva $[12,14,61]$. From fish to humans, FCGBP is a highly upregulated defense gene after bacterial or viral infections and it regulates pathogen attachment $[63,64]$. Thus, it is speculated that FCGBP is involved in the clearing of microorganisms and prevents bacterial infiltration [27]. It has even been suggested to act as a viral trap for HIV-antibody complexes [65]. Generally, FCGBP would be well suited to bind to salivary IgG, which mainly derives from blood through passive leakage $[4,66]$. Currently, the role of TFF3 in the TFF3-FCGBP heterodimer is not established, but TFF3 (and maybe also TFF1) could modulate the binding to microorganisms due to their lectin activities.

Of special note, TFF3 could also interact with another constituent of saliva, i.e., the glycoprotein DMBT1gp340, a known salivary scavenger and agglutinin (SALSA), or salivary agglutinin (SAG), which has important functions in innate immunity (for reviews, see $[67,68])$. DMBT1 appears in many body fluids and its glycosylation seems to be tissue specific $[67,69]$. Calcium-dependent binding of DMBT1 ${ }^{g p} 340$ and recombinant homodimeric TFF3 was observed in vitro [69]. In contrast, no binding was observed with monomeric TFF3 or TFF2 [69]. DMBT1 9 p340 is a repetitive glycoprotein containing mainly scavenger receptor cysteine-rich (SRCR) domains linked by short proline-rich segments (Figure 2B) [68]. On the one hand, it is able to aggregate Streptococcus mutans and S. sanguis as well as influenza A virus (maybe via its SRCR domains) promoting their clearance from the oral cavity $[2,67]$. On the other hand, DMBT1gp340 probably interacts via its mannose and fucose structures with the C-type lectin receptors DC-SIGN and Langerin, which prevented binding of Candida albicans and Escheria coli to these receptors [70]. Furthermore, DMBT1gp340 binds to a variety of host proteins, such as surfactant proteins, lactoferrin, MUC5B, galectin 3 , and even TFF2 $[67,71]$. Currently, there are no reports demonstrating an interaction of TFF3 and DMBT1 ${ }^{g p 340}$ also in vivo. However, a lectin interaction might be possible and this would depend on the glycosylation status, which is tissue specific.

Furthermore, an interaction of homodimeric TFF3 (and even TFF3-FCGBP) with salivary mucins cannot be excluded at the moment and has to be considered thoroughly. This could be of importance as it could affect the viscoelastic properties of salivary mucus. Of special note, the TFF3 concentration in the cervical mucus plug was reported to be correlated with the viscoelastic properties [72]. Remarkably, the gel-forming mucin MUC5B is a major constituent in both the cervicovaginal mucus barrier as well as the saliva $[10,73]$. Generally, a lectin interaction is most likely as homodimeric TFF3 has documented lectin activities (for reviews, see [27,28]).

Taken together, all three TFF3, FCGBP and DMBT1 ${ }^{\mathrm{gp} 340}$ are synthesized by mucous epithelia and are involved in mucosal innate immune defense mechanisms. Generally, they could form a complex interaction network. Of special note, Dmbt1-deficient (Dmbt ${ }^{\mathrm{KO}}$ ) mice show the same phenotype as $T f f 3^{\mathrm{KO}}$ mice, i.e., they react extremely sensitively in a dextran sulfate sodium (DSS)-induced colitis model $[67,74]$. Here, particularly TFF3, which together with FCGBP is mainly secreted by intestinal goblet cells, seems to strengthen the outer colonic mucus barrier by inhibiting microbial attachment, supporting their clearance, and inhibiting penetration of the inner mucus layer (for reviews, see [28,33]). A similar mechanism could well protect the oral cavity and the esophagus. 


\subsection{Summary}

Taken together, the protective roles of TFF peptides seem to differ at the mechanistic level [27]. TFF3 is the major salivary TFF peptide and large amounts exist as a TFF3FCGBP heterodimer [17]. Thus, TFF3 and FCGBP are expected to play a key role in oral and esophageal protection. In Table 1, the possible roles of salivary TFF peptides are summarized.

Table 1. Possible roles of salivary TFF peptides in oral and esophageal protection. The different forms of TFF3 are shown off bold as TFF3 is the predominant TFF peptide in the saliva.

\begin{tabular}{ccc}
\hline TFF Peptides & Possible Role of Salivary TFF Peptides & References \\
\hline TFF1 monomer & Scavenger for ROS and RNS & {$[27,34-36]$} \\
{$[27,32]$} & {$[40]$} & {$[34]$} \\
TFF1 homodimer & Intracellular chaperone (ER) & Interaction with H. pylori \\
TFF2 & Binding to MUC6 (esophagogastric junction) & {$[27,28,32,33]$} \\
& Weak motogenic activity & {$[28,32]$} \\
TFF3 homodimer & Anti-inflammatory effect & {$[27,33,41]$} \\
TFF3-FCGBP & Binding to MUC6 (esophagogastric junction) & {$[27,28,32,33,53,54]$} \\
{$[33,69]$} & {$[27,33]$}
\end{tabular}

\section{Therapeutic Potential and Clinical Perspectives}

\subsection{Saliva, Esophagus and Esophagogastric Junction}

Saliva contains high amounts of nitrate, about 10-20 times higher than in plasma [38]. This leads to the formation of nitric oxide and peroxynitrite, particularly at the delicate esophagogastric junction as this is the primary site of acidification by the gastric juice (see also Section 2.1) [38,39]. This is probably an important factor for the development of adenocarcinoma at the esophagogastric junction [39]. Of note, in patients with gastro-esophageal reflux disease, the anatomical location where saliva meets the gastric juice is somewhat changed towards the distal esophagus [39]. Remarkably, TFF3 expression is increased at the esophagogastric junction in gastro-esophageal reflux disease [75]. Furthermore, saliva also seems to be a pivotal player in the pathogenesis of oropharyngeal cancer $[4,76]$. Here, ROS play a key role and the addition of glutathione with its free thiol group as antioxidant is protective against damages by aldehydes from cigarette smoke [76]. Additionally, monomeric TFF1 may also be protective here (see Section 2.1).

In humans, TFF3 is the predominant TFF peptide in the salivary glands, and saliva and relatively little TFF3 (and no TFF1 and TFF2) is synthesized in the few esophageal submucosal glands [46]. Thus, the human esophagus seems to rely on protection by the saliva. Of special note, and in contrast, the esophagus of the frog Xenopus laevis is protected by massive own synthesis of an ortholog of TFF2, i.e., xP4, by esophageal goblet cells $[44,77]$.

\subsection{TFF Peptides and Their Use in Chemo- and Radiotherapy and in Artificial Saliva}

In the past, TFF peptides have been repeatedly used to protect mucous epithelia from damage (for compilation and reviews, see [78-80]). For example, Tff3 ${ }^{\mathrm{KO}}$ mice were more susceptible to chemotherapy- or radiotherapy-induced intestinal damages and oral application of recombinant TFF3 reduced intestinal mucositis [81]. Subsequently, an oral spray of human dimeric recombinant TFF3 was successfully used in a phase II study to treat colorectal cancer patients in order to reduce chemotherapy-induced oral mucositis [82]. In another attempt, all three TFF peptides delivered by genetically modified Lactococcus lactis were shown to prevent DSS-induced colitis in mice [83]. Later, a mouth rinse formulation of L. lactis-secreting TFF1, coded AG013, was applied to reduce radiation-induced oral 
mucositis in a hamster model [84]. Finally, these positive results were confirmed in a phase Ib study, where patients with locally advanced head and neck cancer (LAHNC) were treated with AG013 during chemotherapy (35\% reduction in percentage of days with ulcerative oral mucositis) [85]. Taken together, the protective effects from chemotherapy- or radiotherapy-induced oral mucositis might be due to the weak motogenic and antiapoptotic effects of TFF peptides as well as by anti-inflammatory effects, which could be triggered by binding to the carbohydrate moiety of numerous transmembrane glycoproteins (for reviews, see $[27,28,32])$.

Pharmacological inhibition of TFF3 dimerization by a synthetic drug was reported to enhance the sensitivity of colorectal carcinoma to chemotherapy [86]. Thus, on the one hand, TFF peptides (especially homodimeric TFF3) can be expected to protect from chemotherapy- or radiotherapy-induced oral mucositis. On the other hand, the inhibition of TFF3 dimerization may positively support the effect of chemotherapy. Thus, the application particularly of homodimeric TFF3 in oral cancer patients during chemotherapy needs caution and should be investigated in detail as it has the potential to act as a double-edged sword.

TFF3, together with FCGBP, could play a major role in the innate immune defense of the oral cavity and the esophagus (see Section 2.3 and Table 1). Thus, the application of TFF3-FCGBP and/or FCGPB seems to be a novel promising strategy to protect the oral cavity from microbial infections, which are typical side effects of radiotherapy and chemotherapy [87]. In addition to radiotherapy or chemotherapy, reduced saliva production may also be caused by certain diseases, medications, or aging, which leads to a chronic sensation of a dry mouth called xerostomia $[3,88]$. Currently, there is still a need for the development of better formulations of saliva substitutes, i.e., artificial saliva, and more sophisticated strategies are needed [88]. Besides rheological and lubricating effects, artificial saliva should support wound healing and have antimicrobial properties [88]. Particularly the latter two properties are important for the maintenance of a healthy oral epithelial barrier [89]. A combination of TFF peptides, FCGBP, and DMBT1gp340 would be promising to support both wound healing and antimicrobial defense. Currently, there is a formulation commercially available from a porcine gastric mucin preparation, which contains relatively large amounts of TFF2, but no detectable levels of TFF1 or TFF3 [90]. However, TFF2 is the least abundant TFF peptide in human saliva and thus this formulation does not reflect the natural situation of TFF peptides in human saliva.

Funding: This research received no external funding.

Acknowledgments: I thank Daniela Lorenz (Otto-von-Guericke University, Magdeburg) for her secretarial help, and Jonathan A. Lindquist (Otto-von-Guericke University, Magdeburg) for his valuable comments on the manuscript.

Conflicts of Interest: The author declares no conflict of interest.

$\begin{array}{ll}\text { Abbreviations } \\ \text { DMBT1 } & \text { Deleted in Malignant Brain Tumor 1 } \\ \text { DSS } & \text { Dextran sulfate sodium } \\ \text { FCGBP } & \text { IgG Fc binding protein } \\ \text { ROS } & \text { Reactive oxygen species } \\ \text { SRCR } & \text { Scavenger receptor cysteine-rich } \\ \text { TFF } & \text { Trefoil factor family }\end{array}$

\section{References}

1. Humphrey, S.P.; Williamson, R.T. A review of saliva: Normal composition, flow, and function. J. Prosthet. Dent. 2001, 85, 162-169. [CrossRef]

2. Amerongen, A.N.; Veerman, E.C.I. Saliva-The defender of the oral cavity. Oral Dis. 2002, 8, 12-22. [CrossRef]

3. Dodds, M.W.J.; Johnson, D.A.; Yeh, C.-K. Health benefits of saliva: A review. J. Dent. 2005, 33, 223-233. [CrossRef]

4. Tabak, L.A. In defense of the oral cavity: The protective role of the salivary secretions. Pediatr. Dent. 2006, 28, 110-117. 
5. Lynge Pedersen, A.M.; Belstrøm, D. The role of natural salivary defences in maintaining a healthy oral microbiota. J. Dent. 2019, 80 (Suppl. 1), S3-S12. [CrossRef]

6. Amado, F.M.L.; Ferreira, R.P.; Vitorino, R. One decade of salivary proteomics: Current approaches and outstanding challenges. Clin. Biochem. 2013, 46, 506-517. [CrossRef]

7. Goldoni, R.; Scolaro, A.; Boccalari, E.; Dolci, C.; Scarano, A.; Inchigolo, F.; Ravazzani, P.; Muti, P.; Tartaglia, G. Malignancies and biosensors: A focus on oral cancer detection through salivary biomarkers. Biosensors 2021, 11, 396. [CrossRef] [PubMed]

8. Zallocco, L.; Giusti, L.; Ronci, M.; Mussini, A.; Trerotola, M.; Mazzoni, M.R.; Lucacchini, A.; Sebastiani, L. Salivary Proteome Changes in Response to Acute Psychological Stress Due to an Oral Exam Simulation in University Students: Effect of an Olfactory Stimulus. Int. J. Mol. Sci. 2021, 22, 4295. [CrossRef] [PubMed]

9. Finamore, F.; Cecchettini, A.; Ceccherini, E.; Signore, G.; Ferro, F.; Rocchiccioli, S.; Baldini, C. Characterization of Extracellular Vesicle Cargo in Sjögren's Syndrome through a SWATH-MS Proteomics Approach. Int. J. Mol. Sci. 2021, 22, 4864. [CrossRef]

10. Frenkel, E.S.; Ribbeck, K. Salivary mucins in host defense and disease prevention. J. Oral Microbiol. 2015, 7, 29759. [CrossRef] [PubMed]

11. Ligtenberg, A.J.; Veerman, E.C.; Nieuw Amerongen, A.V.; Mollenhauer, J. Salivary agglutinin/glycoprotein-340/DMBT1: A single molecule with variable composition and with different functions in infection, inflammation and cancer. Biol. Chem. 2007, 388, 1275-1289. [CrossRef] [PubMed]

12. Denny, P.; Hagen, F.K.; Hardt, M.; Liao, L.; Yan, W.; Arellanno, M.; Bassilian, S.; Bedi, G.S.; Boontheung, P.; Cociorva, D.; et al. The proteomes of human parotid and submandibular/sublingual gland salivas collected as the ductal secretions. J. Proteome Res. 2008, 7, 1994-2006. [CrossRef] [PubMed]

13. Bräuer, L.; Möschter, S.; Beileke, S.; Jäger, K.; Garreis, F.; Paulsen, F.P. Human parotid and submandibular glands express and secrete surfactant proteins A, B, C and D. Histochem. Cell Biol. 2009, 132, 331-338. [CrossRef] [PubMed]

14. Kouznetsova, I.; Gerlach, K.L.; Zahl, C.; Hoffmann, W. Expression analysis of human salivary glands by laser microdissection: Differences between submandibular and labial glands. Cell. Physiol. Biochem. 2010, 26, 375-382. [CrossRef]

15. Jagla, W.; Wiede, A.; Hinz, M.; Dietzmann, K.; Gülicher, D.; Gerlach, K.L.; Hoffmann, W. Secretion of TFF-peptides by human salivary glands. Cell Tissue Res. 1999, 298, 161-166. [CrossRef] [PubMed]

16. Storesund, T.; Schreurs, O.; Messelt, E.B.; Kolltveit, K.M.; Schenck, K. Trefoil factor family 3 expression in the oral cavity. Eur. J. Oral Sci. 2009, 117, 636-643. [CrossRef]

17. Houben, T.; Harder, S.; Schlüter, H.; Kalbacher, H.; Hoffmann, W. Different Forms of TFF3 in the Human Saliva: Heterodimerization with IgG Fc Binding Protein (FCGBP). Int. J. Mol. Sci. 2019, 20, 5000. [CrossRef]

18. Samson, M.H.; Chaiyarit, P.; Nortvig, H.; Vestergaard, E.M.; Ernst, E.; Nexo, E. Trefoil factor family peptides in human saliva and cyclical cervical mucus. Method evaluation and results on healthy individuals. Clin. Chem. Lab. Med. 2011, 49, 861-868. [CrossRef]

19. Devine, D.A.; High, A.S.; Owen, P.J.; Poulsom, R.; Bonass, W.A. Trefoil factor expression in normal and diseased human salivary glands. Hum. Pathol. 2000, 31, 509-515. [CrossRef]

20. Kutta, H.; May, J.; Jaehne, M.; Münscher, A.; Paulsen, F.P. Antimicrobial defence mechanisms of the human parotid duct. J. Anat. 2006, 208, 609-619. [CrossRef]

21. Chaiyarit, P.; Utrawichian, A.; Leelayuwat, C.; Vatanasapt, P.; Chanchareonsook, N.; Samson, M.H.; Giraud, A.S. Investigation of trefoil factor expression in saliva and oral mucosal tissues of patients with oral squamous cell carcinoma. Clin. Oral Investig. 2012, 16, 1549-1556. [CrossRef]

22. Chaiyarit, P.; Klanrit, P.; Phothipakdee, P.; Subarnbhesaj, A.; Thongprasom, K.; Giraud, A.S. Trefoil factor expression by immunohistochemistry in patients with oral lichen planus. Asian Biomed. 2014, 8, 743-749. [CrossRef]

23. Siber-Hoogeboom, R.; Schicht, M.; Hoogeboom, S.; Paulsen, F.P.; Traxdorf, M. Obstructive sleep apnea and rhonchopathy are associated with downregulation of trefoil factor family peptide 3 (TFF3)-Implications of changes in oral mucus composition. PLoS ONE 2017, 12, e0185200.

24. Chaiyarit, P.; Chayasadom, A.; Wara-Aswapati, N.; Hormdee, D.; Sittisomwong, S.; Nakaresisoon, S.; Samson, M.H.; Pitiphat, W.; Giraud, A.S. Trefoil factors in saliva and gingival tissues of patients with chronic periodontitis. J. Periodontol. 2012, 83, 1129-1138. [CrossRef]

25. Verey, F.; Nexo, E.; Greenwood, R.; Berry, M.; Corfield, A.P. Trefoil factor family peptides are increased in the saliva of children with mucositis. Clin. Chem. Lab. Med. 2011, 49, 2051-2055. [CrossRef] [PubMed]

26. Chaiyarit, P.; Klanrit, P.; Photipakdee, P.; Subarnbhesaj, A.; Giraud, A.S. Increased immunoexpression of trefoil factors in salivary gland tumors. Clin. Oral Investig. 2014, 18, 1305-1312. [CrossRef] [PubMed]

27. Hoffmann, W. Trefoil Factor Family (TFF) Peptides and Their Diverse Molecular Functions in Mucus Barrier Protection and More: Changing the Paradigm. Int. J. Mol. Sci. 2020, 21, 4535. [CrossRef]

28. Hoffmann, W. Trefoil Factor Family (TFF) Peptides. Encyclopedia 2021, 1, 974-987. [CrossRef]

29. Choudhary, A.; Smitha, C.N.; Suresh, D.K. Trefoils: An unexplored natural protective shield of oral cavity. J. Oral Biol. Craniofac. Res. 2015, 5, 226-231. [CrossRef]

30. Thim, L. Trefoil peptides: From structure to function. Cell. Mol. Life Sci. 1997, 53, 888-903. [CrossRef]

31. Thim, L.; May, F.E.B. Structure of mammalian trefoil factors and functional insights. Cell. Mol. Life Sci. 2005, 62, 2956-2973. [CrossRef] 
32. Hoffmann, W. Trefoil Factor Family (TFF) Peptides and Their Links to Inflammation: A Re-evaluation and New Medical Perspectives. Int. J. Mol. Sci. 2021, 22, 4909. [CrossRef]

33. Hoffmann, W. Trefoil Factor Family (TFF) Peptides and their Different Roles in the Mucosal Innate Immune Defense and More: An Update. Curr. Med. Chem. 2021, 28, 7387-7399. [CrossRef] [PubMed]

34. Heuer, J.; Heuer, F.; Stürmer, R.; Harder, S.; Schlüter, H.; Braga Emidio, N.; Muttenthaler, M.; Jechorek, D.; Meyer, F.; Hoffmann, W. The Tumor Suppressor TFF1 Occurs in Different Forms and Interacts with Multiple Partners in the Human Gastric Mucus Barrier: Indications for Diverse Protective Functions. Int. J. Mol. Sci. 2020, 21, 2508. [CrossRef]

35. Znalesniak, E.B.; Salm, F.; Hoffmann, W. Molecular Alterations in the Stomach of Tff1-Deficient Mice: Early Steps in Antral Carcinogenesis. Int. J. Mol. Sci. 2020, 21, 644. [CrossRef] [PubMed]

36. Stürmer, R.; Reising, J.; Hoffmann, W. The TFF Peptides xP1 and xP4 Appear in Distinctive Forms in the Xenopus laevis Gastric Mucosa: Indications for Different Protective Functions. Int. J. Mol. Sci. 2019, 20, 6052. [CrossRef]

37. Allaoui, A.; Botteaux, A.; Dumont, J.E.; Hoste, C.; De Deken, X. Dual oxidases and hydrogen peroxide in a complex dialogue between host mucosae and bacteria. Trends Mol. Med. 2009, 15, 571-579. [CrossRef]

38. Duncan, C.; Li, H.; Dykhuizen, R.; Frazer, R.; Johnston, P.; MacKnight, G.; Smith, L.; Lamza, K.; McKenzie, H.; Batt, L.; et al. Protection against oral and gastrointestinal diseases: Importance of dietary nitrate intake, oral nitrate reduction and enterosalivary nitrate circulation. Comp. Biochem. Physiol. 1997, 118A, 939-948. [CrossRef]

39. McColl, K.E.L. When saliva meets acid: Chemical warfare at the oesophagogastric junction. Gut 2005, 54, 1-3. [CrossRef] [PubMed]

40. Clyne, M.; May, F.E.B. The interaction of Helicobacter pylori with TFF1 and its role in mediating the tropism of the bacteria within the stomach. Int. J. Mol. Sci. 2019, 20, 4400. [CrossRef]

41. Hoffmann, W. TFF2, a MUC6-binding lectin stabilizing the gastric mucus barrier and more. Int. J. Oncol. 2015, 47, 806-816. [CrossRef]

42. Karasawa, F.; Shiota, A.; Goso, Y.; Kobayashi, M.; Sato, Y.; Masumoto, J.; Fujiwara, M.; Yokosawa, S.; Muraki, T.; Miyagawa, S.; et al. Essential role of gastric gland mucin in preventing gastric cancer in mice. J. Clin. Investig. 2012, 122, 923-934. [CrossRef] [PubMed]

43. Heuer, F.; Stürmer, R.; Heuer, J.; Kalinski, T.; Lemke, A.; Meyer, F.; Hoffmann, W. Different forms of TFF2, a lectin of the human gastric mucus barrier: In vitro binding studies. Int. J. Mol. Sci. 2019, 20, 5871. [CrossRef]

44. Schwarz, H.; Hoffmann, W. Subcellular Localization of the TFF Peptides xP1 and xP4 in the Xenopus laevis Gastric/Esophageal Mucosa: Different Secretion Modes Reflecting Diverse Protective Functions. Int. J. Mol. Sci. 2020, 21, 761. [CrossRef] [PubMed]

45. Stürmer, R.; Müller, S.; Hanisch, F.-G.; Hoffmann, W. Porcine gastric TFF2 is a mucus constituent and differs from pancreatic TFF2. Cell. Physiol. Biochem. 2014, 33, 895-904. [CrossRef]

46. Kouznetsova, I.; Kalinski, T.; Peitz, U.; Mönkemüller, K.E.; Kalbacher, H.; Vieth, M.; Meyer, F.; Roessner, A.; Malfertheiner, P.; Lippert, H.; et al. Localization of TFF3 peptide in human esophageal submucosal glands and gastric cardia: Differentiation of two types of gastric pit cells along the rostro-caudal axis. Cell Tissue Res. 2007, 328, 365-374. [CrossRef]

47. Khummuang, S.; Phanphrom, W.; Laopajon, W.; Kasinrerk, W.; Chaiyarit, P.; Pata, S. Production of Monoclonal Antibodies against Human Trefoil Factor 3 and Development of a Modified-Sandwich ELISA for Detection of Trefoil Factor 3 Homodimer in Saliva. Biol. Proced. Online 2017, 19, 14. [CrossRef] [PubMed]

48. Neubert, H.; Gale, J.; Muirhead, D. Online high-flow peptide immunoaffinity enrichment and nanoflow LC-MS/MS: Assay development for total salivary pepsin/pepsinogen. Clin. Chem. 2010, 56, 1413-1423. [CrossRef]

49. Kinoshita, M.; Kume, E.; Igarashi, S.; Saito, N.; Narita, H. Role of salivary mucin in the protection of rat esophageal mucosa from acid and pepsin-induced injury. Am. J. Physiol. 1999, 277, G796-G800. [CrossRef]

50. Wiede, A.; Jagla, W.; Welte, T.; Kohnlein, T.; Busk, H.; Hoffmann, W. Localization of TFF3, a new mucus-associated peptide of the human respiratory tract. Am. J. Respir. Crit. Care Med. 1999, 159, 1330-1335. [CrossRef] [PubMed]

51. Wiede, A.; Hinz, M.; Canzler, E.; Franke, K.; Quednow, C.; Hoffmann, W. Synthesis and localization of the mucin-associated TFF-peptides in the human uterus. Cell Tissue Res. 2001, 303, 109-115. [CrossRef] [PubMed]

52. Cho, S.Y.; Klemke, R.L. Extracellular-regulated kinase activation and CAS/Crk coupling regulate cell migration and suppress apoptosis during invasion of the extracellular matrix. J. Cell Biol. 2000, 149, 223-236. [CrossRef]

53. Storesund, T.; Hayashi, K.; Kolltveit, K.M.; Bryne, M.; Schenck, K. Salivary trefoil factor 3 enhances migration of oral keratinocytes. Eur. J. Oral Sci. 2008, 116, 135-140. [CrossRef] [PubMed]

54. Storesund, T.; Schenck, K.; Osmundsen, H.; Røed, A.; Helgeland, K.; Kolltveit, K.M. Signal transduction and gene transcription induced by TFF3 in oral keratinocytes. Eur. J. Oral Sci. 2009, 117, 511-517. [CrossRef]

55. Dieckow, J.; Brandt, W.; Hattermann, K.; Schob, S.; Schulze, U.; Mentlein, R.; Ackermann, P.; Sel, S.; Paulsen, F.P. CXCR4 and CXCR7 mediate TFF3-induced cell migration independently from the ERK1/2 signaling pathway. Investig. Ophthalmol. Sci. 2016, 57, 56-65. [CrossRef] [PubMed]

56. Hoffmann, W. Trefoil factor family (TFF) peptides and chemokine receptors: A promising relationship. J. Med. Chem. 2009, 52, 6505-6510. [CrossRef]

57. Chinery, R.; Playford, R.J. Combined intestinal trefoil factor and epidermal growth factor is prophylactic against indomethacininduced gastric damage in the rat. Clin. Sci. 1995, 88, 401-403. [CrossRef] [PubMed] 
58. Chwieralski, C.E.; Schnurra, I.; Thim, L.; Hoffmann, W. Epidermal growth factor and trefoil factor family 2 synergistically trigger chemotaxis on BEAS-2B cells via different signaling cascades. Am. J. Respir. Cell Mol. Biol. 2004, 31, 528-537. [CrossRef] [PubMed]

59. Dürer, U.; Hartig, R.; Bang, S.; Thim, L.; Hoffmann, W. TFF3 and EGF induce different migration patterns of intestinal epithelial cells in vitro and trigger increased internalization of E-cadherin. Cell. Physiol. Biochem. 2007, 20, 329-346. [CrossRef]

60. Albert, T.K.; Laubinger, W.; Müller, S.; Hanisch, F.G.; Kalinski, T.; Meyer, F.; Hoffmann, W. Human intestinal TFF3 forms disulfide-linked heteromers with the mucus-associated FCGBP protein and is released by hydrogen sulfide. J. Proteome Res. 2010, 9, 3108-3117. [CrossRef]

61. Kobayashi, K.; Ogata, H.; Morikawa, M.; Iijima, S.; Harada, N.; Yoshida, T.; Brown, W.R.; Inoue, N.; Hamada, Y.; Ishii, H.; et al. Distribution and partial characterisation of IgG Fc binding protein in various mucin producing cells and body fluids. Gut 2002, 51, 169-176. [CrossRef]

62. Lang, T.; Klasson, S.; Larsson, E.; Johansson, M.E.; Hansson, G.C.; Samuelsson, T. Searching the Evolutionary Origin of Epithelial Mucus Protein Components-Mucins and FCGBP. Mol. Biol. Evol. 2016, 33, 1921-1936. [CrossRef]

63. Li, C.; Wang, R.; Su, B.; Luo, Y.; Terhune, J.; Beck, B.; Peatman, E. Evasion of mucosal defenses during Aeromonas hydrophila infection of channel catfish (Ictalurus punctatus) skin. Dev. Comp. Immunol. 2013, 39, 447-455. [CrossRef]

64. Wang, Y.; Liu, Y.; Liu, H.; Zhang, Q.; Song, H.; Tang, J.; Fu, J.; Wang, X. FcGBP was upregulated by HPV infection and correlated to longer survival time of HNSCC patients. Oncotarget 2017, 8, 86503-86514. [CrossRef]

65. Schwartz, J.L. Fcgbp-A Potential Viral Trap in RV144. Open AIDS J. 2014, 8, 21-24. [CrossRef]

66. Brandtzaeg, P. Secretory immunity with special reference to the oral cavity. J. Oral Microbiol. 2013, 5, 20401. [CrossRef]

67. Madsen, J.; Mollenhauer, J.; Holmskov, U. Review: Gp-340/DMBT1 in mucosal innate immunity. Innate Immun. 2010, 16, 160-167. [CrossRef] [PubMed]

68. Reichhardt, M.P.; Holmskov, U.; Meri, S. SALSA-A dance on a slippery floor with changing partners. Mol. Immunol. 2017, 89, 100-110. [CrossRef] [PubMed]

69. Madsen, J.; Sorensen, G.L.; Nielsen, O.; Tornøe, I.; Thim, L.; Fenger, C.; Mollenhauer, J.; Holmskov, U. A variant form of the human deleted in malignant brain tumor 1 (DMBT1) gene shows increased expression in inflammatory bowel diseases and interacts with dimeric trefoil factor 3 (TFF3). PLoS ONE 2013, 8, e64441.

70. Boks, M.A.; Gunput, S.T.; Kosten, I.; Gibbs, S.; van Vliet, S.J.; Ligtenberg, A.J.; van Kooyk, Y. The Human Glycoprotein Salivary Agglutinin Inhibits the Interaction of DC-SIGN and Langerin with Oral Micro-Organisms. J. Innate Immun. 2016, 8, 350-361. [CrossRef]

71. Thim, L.; Mørtz, E. Isolation and characterization of putative trefoil peptide receptors. Regul. Pept. 2000, 90, 61-68. [CrossRef]

72. Bastholm, S.K.; Samson, M.H.; Becher, N.; Hansen, L.K.; Stubbe, P.R.; Chronakis, I.S.; Nexo, E.; Uldbjerg, N. Trefoil factor peptide 3 is positively correlated with the viscoelastic properties of the cervical mucus plug. Acta Obstetr. Gynecol. Scand. 2017, 96, 47-52. [CrossRef]

73. Lacroix, G.; Gouyer, V.; Gottrand, F.; Desseyn, J.-L. The cervicovaginal mucus barrier. Int. J. Mol. Sci. 2020, 21, 8266. [CrossRef] [PubMed]

74. Mashimo, H.; Wu, D.C.; Podolsky, D.K.; Fishman, M.C. Impaired defense of intestinal mucosa in mice lacking intestinal trefoil factor. Science 1996, 274, 262-265. [CrossRef] [PubMed]

75. Peitz, U.; Kouznetsova, I.; Wex, T.; Gebert, I.; Vieth, M.; Roessner, A.; Hoffmann, W.; Malfertheiner, P. TFF3 expression at the esophagogastric junction is increased in gastro-esophageal reflux disease (GERD). Peptides 2004, 25, 771-777. [CrossRef] [PubMed]

76. Reznick, A.Z.; Hershkovich, O.; Nagler, R.M. Saliva-A pivotal player in the pathogenesis of oropharyngeal cancer. Br. J. Cancer 2004, 91, 111-118. [CrossRef]

77. Jagla, W.; Wiede, A.; Kölle, S.; Hoffmann, W. Differential expression of the TFF-peptides xP1 and xP4 in the gastrointestinal tract of Xenopus laevis. Cell Tissue Res. 1998, 291, 13-18. [CrossRef]

78. Hoffmann, W.; Jagla, W. Cell type specific expression of secretory TFF peptides: Colocalization with mucins and synthesis in the brain. Int. Rev. Cytol. 2002, 213, 147-188.

79. Kjellev, S. The trefoil factor family-Small peptides with multiple functionalities. Cell. Mol. Life Sci. 2009, 66, 1350-1369. [CrossRef] [PubMed]

80. Braga Emidio, N.; Hoffmann, W.; Brierley, S.M.; Muttenthaler, M. Trefoil factor family: Unresolved questions and clinical perspectives. Trends Biochem. Sci. 2019, 44, 387-390. [CrossRef] [PubMed]

81. Beck, P.L.; Wong, J.F.; Li, Y.; Swaminathan, S.; Xavier, R.J.; Devaney, K.L.; Podolsky, D.K. Chemotherapy- and radiotherapyinduced intestinal damage is regulated by intestinal trefoil factor. Gastroenterology 2004, 126, 796-808. [CrossRef] [PubMed]

82. Peterson, D.E.; Barker, N.P.; Akhmadullina, L.I.; Rodionova, I.; Sherman, N.Z.; Davidenko, I.S.; Rakovskaya, G.N.; Gotovkin, E.A.; Shinkarev, S.A.; Kopp, M.V.; et al. Phase II, randomized, double-blind, placebo-controlled study of recombinant human intestinal trefoil factor oral spray for prevention of oral mucositis in patients with colorectal cancer who are receiving fluorouracil-based chemotherapy. J. Clin. Oncol. 2009, 27, 4333-4338. [CrossRef] [PubMed]

83. Vandenbroucke, K.; Hans, W.; Van Huysse, J.; Neirynck, S.; Demetter, P.; Remaut, E.; Rottiers, P.; Steidler, L. Active delivery of trefoil factors by genetically modified Lactococcus lactis prevents and heals acute colitis in mice. Gastroenterology 2004, 127, 502-513. [CrossRef] 
84. Caluwaerts, S.; Vandenbroucke, K.; Steidler, L.; Neirynck, S.; Vanhoenacker, P.; Corveleyn, S.; Watkins, B.; Sonis, S.; Coulie, B.; Rottiers, P. AG013, a mouth rinse formulation of Lactococcus lactis secreting human Trefoil Factor 1, provides a safe and efficacious therapeutic tool for treating oral mucositis. Oral Oncol. 2010, 46, 564-570. [CrossRef]

85. Limaye, S.A.; Haddad, R.I.; Cilli, F.; Sonis, S.T.; Colevas, A.D.; Brennan, M.T.; Hu, K.S.; Murphy, B.A. Phase 1b, multicenter, single blinded, placebo-controlled, sequential dose escalation study to assess the safety and tolerability of topically applied AG013 in subjects with locally advanced head and neck cancer receiving induction chemotherapy. Cancer 2013, 119, 4268-4276. [CrossRef]

86. Chen, R.-M.; Chiou, Y.-S.; Chong, Q.-Y.; Poh, H.-M.; Tan, T.-Z.; Zhang, M.-Y.; Ma, L.; Zhu, T.; Pandey, V.; Kumar, A.P.; et al. Pharmacological Inhibition of TFF3 Enhances Sensitivity of CMS4 Colorectal Carcinoma to 5-Fluorouracil through Inhibition of p44/42 MAPK. Int. J. Mol. Sci. 2019, 20, 6215. [CrossRef]

87. van Vliet, M.J.; Harmsen, H.J.; de Bont, E.S.; Tissing, W.J. The role of intestinal microbiota in the development and severity of chemotherapy-induced mucositis. PLoS Pathog. 2010, 6, e1000879. [CrossRef]

88. Łysik, D.; Niemirowicz-Laskowska, K.; Bucki, R.; Tokajuk, G.; Mystkowska, J. Artificial saliva: Challenges and future perspectives for the treatment of xerostomia. Int. J. Mol. Sci. 2019, 20, 3199. [CrossRef] [PubMed]

89. Wang, S.S.; Tang, Y.L.; Pang, X.; Zheng, M.; Tang, Y.J.; Liang, X.H. The maintenance of an oral epithelial barrier. Life Sci. 2019, 227, 129-136. [CrossRef]

90. Stürmer, R.; Harder, S.; Schlüter, H.; Hoffmann, W. Commercial porcine gastric mucin preparations, also used as artificial saliva, are a rich source for the lectin TFF2: In vitro binding studies. ChemBioChem 2018, 19, 2598-2608. [CrossRef] 